Special Issue: Agricultural Productivity and Sustainability Improvement in Tropical Region

\title{
The Effect of Abiotic Factors and Elevation on the Diversity of Plant Parasitic Nematodes in Garlic on Central Java, Indonesia
}

\author{
Ayu Suci Wulandari ${ }^{1}$, Siwi Indarti ${ }^{1,2 *}$, Muhannad Illayan Massadeh ${ }^{3}$ and Nguyen Van Minh ${ }^{4}$
}

${ }^{1}$ Department of Plant Protection, Faculty of Agriculture, Universitas Gadjah Mada Jln. Flora No.1 Bulaksumur, Sleman, Yogyakarta 55281, Indonesia; ' Agrotechnology Innovation Centre (AIC), Universitas Gadjah Mada, Jln. Tanjung Tirto, Kalitirto, Berbah, Tanjung, Sleman, Yogyakarta 55573, Indonesia; ${ }^{3}$ Department of Biological Sciences and Biotechnology, Faculty of Science, The Hashemite University13133, Zarqa, Jordan; ${ }^{4}$ Faculty of Agriculture and Forestry, Tay Nguyen University, 567 Le Duan St. Buon Ma Thuot City, Dak Lak Province, Vietnam, 63100.

Abstract | Plant-parasitic nematodes are one of the most prominent type of pests in garlic (Allium sativum L.). To determine the influence of elevation and soil abiotic factor to abundance and diversity of plant parasitic nematode in garlic crops, this research was conducted Sampling was carried out in four locations: Brebes, Magelang, Tegal and Temanggung, Central Java, Indonesia. Samples of soil, roots and tubers were collected. Soil abiotic factors are taken measurements such as $\mathrm{pH}$, temperature, and organic matter. The altitudes are measured using the Geograpichal Positioning System (GPS). The results showed that there were five parasitic nematodes genera in garlic, that are Ditylenchus sp., Helicotylenchus sp., Hoplolaimus sp., Rotylenchulus sp., and Pratylenchus sp. Abiotic factors as temperature has a positive influence on the abundance of Helicotylenchus sp., $\mathrm{pH}$ has a negative influence on the abundance of Hoplolaimus sp., organic matter has a positive effect on the abundance of Pratylenchus sp.. The diversity index of parasitic nematodes in garlic at various elevations is relatively low, ranging from 0.90 to 1.36 . The dominance of plant parasitic nematodes in garlic at various elevations varies at the elevations $>1600 \mathrm{~m}$ a.s.1, $1201 \mathrm{~m}$ to $1400 \mathrm{~m}$ a.s.l and $<1000 \mathrm{~m}$ a.s.1. The dominating plant parasitic nematode was Ditylenchus sp., found at $1401 \mathrm{~m}$ to $1600 \mathrm{~m}$ a.s.l elevation, the predominant plant parasitic nematode was Helicotylenchus sp., found at $1000 \mathrm{~m}$ to $1200 \mathrm{~m}$ a.s.l elevation, and the dominating plant parasitic nematode was Pratylenchus sp. found at less $1000 \mathrm{~m}$ a.s.l elevation.

Received | May 06, 2021; Accepted | July 27, 2021; Published | October 27, 2021

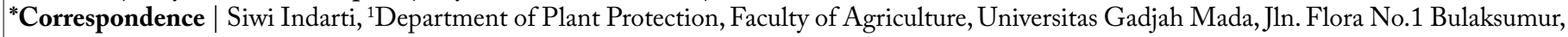
Sleman 55281, Yogyakarta, Indonesia; ${ }^{2}$ Agrotechnology Innovation Centre (AIC), Universitas Gadjah Mada, Jln. Tanjung Tirto, Kalitirto, Berbah, Tanjung, Sleman, Yogyakarta 55573, Indonesia; Email: siwi.indarti@ugm.ac.id

Citation | Wulandari, A.S., S. Indarti, M.I. Massadeh and N.V. Minh. 2021. The effect of abiotic factors and elevation on the diversity of plant parasitic nematodes in garlic on central java, Indonesia. Sarhad Journal of Agriculture, 37(Special issue 1): 75-83.

DOI | https://dx.doi.org/10.17582/journal.sja/2021/37.s1.75.83

Keywords | Allium sativum L., Flagship horticulture, abiotic factor and elevation, Survey of plant parasitic nematodes

\section{Introduction}

$\mathrm{G}$ arlic (Allium sativum L.) is one of the most Important flagship horticultures in Indonesia. Central Java is a suitable area for producing garlic in Indonesia. The area includes Magelang, Tawangmangu, Tegal and Temanggung. Garlic production is bound to be attacked by pests in the field. One kind of the pests causing a pretty high loss yet drawing less concern is plant-parasitic nematodes. Plant-parasitic nematodes are a major type of pest that causes a huge loss on the agricultural production of plants in both tropic and sub-tropic region (Mahmoud and Wafaa, 2021). Garlic crop loss caused by plant-parasitic nematodes reaches $8.8 \%$ to $14.6 \%$ and results in economic loss amounting to USD 100 to 157 billion across the entire country (Nicol et al., 2011). 
According to George and Muktan's (2010), garlic diseases caused by nematodes in New York, symptoms of the severe loss may lead to $80 \%$ to $90 \%$ of the crop loss. The development of nematodes is influenced by several abiotic factors. This becomes a major concern since nematodes life in soil allows direct contact with factors in the soil that may affect their persistence. Abiotic factors such as temperature, humidity and soil texture may affect the abundance of plant-parasitic nematodes. Plant-parasitic nematodes identification in garlic is extremely necessary since there is little information about plant-parasitic nematodes of garlic in Indonesia. Based on the lacking of information of the influence of elevation and soil abiotic factor to abundance and diversity of plant parasitic nematode in garlic crops, this investigation was done. This information may hopefully benefit people in controlling garlic-parasitic nematodes attack and preventing the quarantine pest's entry to the Republic of Indonesia.

\section{Materials and Methods}

\section{Sample collection and soil abiotic factors measure}

The survey was carried out at garlic plantations in Magelang, Temanggung, Brebes and Tegal areas in Central Java from November 2018 to May 2019. Soil abiotic factors observed were temperature, $\mathrm{pH}$ and organic matter. Temperature and $\mathrm{pH}$ are observed using a soil thermometer and $\mathrm{pH}$ meter (Mediatech Soil Survey Instrument Digital 4 in 1 Backlight) by sticking it in the soil with $10 \mathrm{~cm}$ in depth for 10 . whereas organic matter was analysed in the laboratory. The location of the land was divided into five points based on their height above sea level (a.s.l) with the altitude of $<1000 \mathrm{~m}$ a.s.1, $1000 \mathrm{~m}$ to $1200 \mathrm{~m}$ a.s.l, 1 $201 \mathrm{~m}$ to $1400 \mathrm{~m}$ a.s.l, $1401 \mathrm{~m}$ to $1600 \mathrm{~m}$ a.s.l and $>1600 \mathrm{~m}$ a.s.l the altitude are measured using the Geograpichal Positioning System (GPS). Samples were taken based on the morphology of the diseased plant (diagnostic method).

\section{Analyses of nematode population and identification}

The Isolation-Extraction of nematodes from soil samples was carried out using a modification of the Whitehead Tray method (Bezooijen, 2006), while the Isolation-Extraction of nematodes from plant tissues (roots and tubers) was carried out by incubation method (Bezooijen, 2006). Sample with approximately $200 \mathrm{~g}$ of soil and $5 \mathrm{~g}$ of root in each location was taken. Population abundance parasitic nematode counted by multiplying the average number of parasitic nematodes from $5 \mathrm{~mL}$ in 50 nematodes pop- ulation (Rahman et al., 2014). Nematode identification till genus level was done based on morphological characteristics referred to Key to Genera of Plant Parasitic Nematodes (Mai and Peter, 1996).

\section{Relation between abiotic factors and parasitic nematodes abundance}

Relation between abiotic factors such as temperature, $\mathrm{pH}$, organic matter with parasitic nematodes abundance in soils, tubers and roots was analysed using correlation analysis and linear regression through Ms. Excel program.

Diversity of parasitic nematodes analysis based on elevation

Diversity of parasitic nematodes in garlic on various elevation analysed using Shannon diversity index (Ifo et al., 2016), explain in Equation (1).

Where;

$$
\mathrm{H}^{\prime}=-\sum \llbracket \mathrm{Pi} \ln \mathrm{Pi} \rrbracket
$$

$\mathrm{H}^{\prime}=$ Shanon diversity index; $\mathrm{Pi}=$ Abundance index; Noted: $\mathrm{Pi}=\mathrm{ni} / \mathrm{N}, \mathrm{ni}=$ individual number of each genus of nematodes; $\mathrm{N}=$ total number of all genera of nematodes.

\section{Results and Discussion}

\section{Soil abiotic factor characteristics}

The soil $\mathrm{pH}$ of the collected samples varied between 5.4 to 5.9. The concentration of $\mathrm{H}$ ions in soil may vary and fluctuate due to the weather and the vertical distribution of colloidal material on the soil profile (Mulyadi, 2009). The temperature of each altitude were also varied between $22.5{ }^{\circ} \mathrm{C}$ to $25.5^{\circ} \mathrm{C}$. In wet soil, an increase in temperature is slower than that in dry soil although the input of heat on the surface is the same. The heat from the sun will penetrate deeper into wet soil rather than dry soil (Mulyadi, 2009). Organic matter contents in each soil sample were various with range $5.33 \%$ to $11.55 \%$ and the value were categorized in high level when reach more than $5 \%$ (Eviati and Sulaeman, 2009)(Table 1).

Table 1: Soil abiotic factors characteristics at garlic plantations in Central Java.

$\begin{array}{lllll}\text { Location } & \begin{array}{l}\text { Elevation } \\ \text { (m a.s.l) }\end{array} & \begin{array}{l}\text { Tempera- } \\ \text { ture }\left({ }^{\circ} \mathbf{C}\right)\end{array} & \begin{array}{l}\text { pH } \\ \text { Organic } \\ \text { matter (\%) }\end{array} \\ \text { Magelang } & >1600 & 22.5 & 5.9 & 5.33 \\ \text { Brebes } & 1401 \text { to } 1600 & 23 & 5.8 & 6.41 \\ \text { Temanggung } & 1201 \text { to } 1400 & 23.5 & 5.4 & 5.45 \\ \text { Temanggung } & 1000 \text { to } 1200 & 24 & 5.8 & 11.05 \\ \text { Tegal } & <1000 & 25.5 & 5.4 & 11.55\end{array}$

2021 | Volume 37 | Special Issue 1 | Page 76 

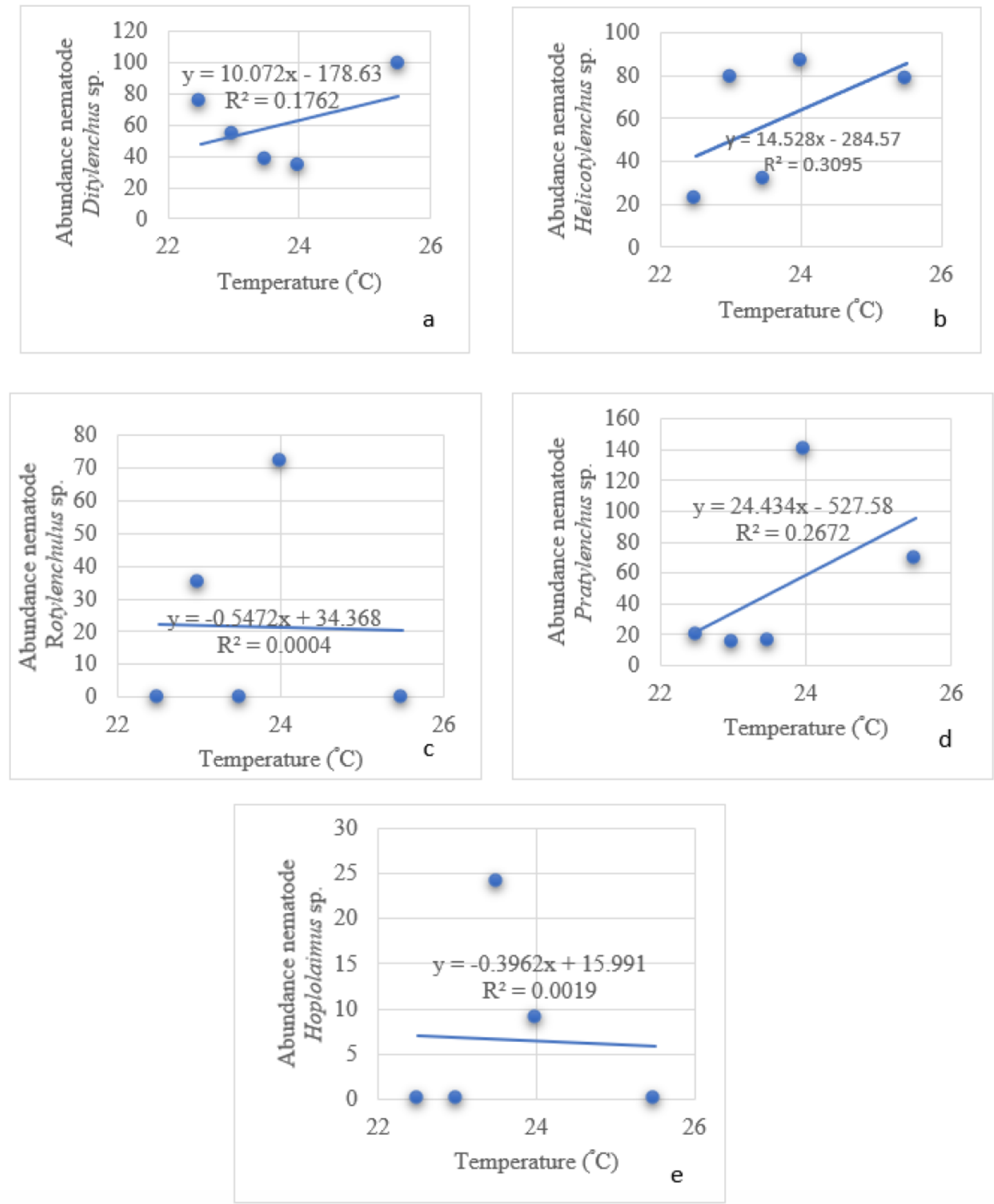

Figure 1: Temperature influences on parasitic Nematodes abundance (a): Ditylenchus sp.; (b) Helicotylenchus sp.; (c) Rotylenchulus sp.; (d) Pratylenchus sp.; (e) Hoplolaimus sp.

Parasitic nematodes abundance on garlic

This research found five genera of parasitic nematodes on garlic at various elevations in Central Java that is Ditylenchus sp., Helicotylenchus sp. Hoplolaimus sp., Rotylenchulus sp., and Pratylenchus sp. The result 2021 | Volume 37 | Special Issue 1 | Page 77 showed that parasitic nematodes on genus Ditylenchus sp. were mostly found at $<1000 \mathrm{~m}$ a.s.l elevation from the root or soil, with 66.67 individuals $5 \mathrm{~g}^{-1} \mathrm{tu}^{-}$ ber and 33 individuals $100 \mathrm{~g}^{-1}$ soil (Table 2). Genus Helicotylenchus sp. was mostly found at $<1000 \mathrm{~m}$ a.s.1 
Table 2: Parasitic nematodes abundance on garlic at various elevation.

\begin{tabular}{lllllllllll} 
Location & Elevation & \multicolumn{3}{l}{ Population $\mathbf{5}$ g tuber } & \multicolumn{3}{c}{ Population/ 100 g soil } \\
& (m a.s.1) & Dit & Hel & Roty & Praty & Dit & Hel & Roty & Praty & Hoplo \\
Magelang & $>1600$ & 64.42 & 22.5 & 0 & 0 & 10.83 & 0 & 0 & 19 & 0 \\
Brebes & 1401 to 1600 & 46.07 & 52.5 & 35 & 0 & 8.4 & 27 & 0 & 18 & 0 \\
Temanggung & 1201 to 1400 & 25.55 & 20 & 0 & 0 & 12 & 0 & 0 & 16 & 24 \\
Temanggung & 1000 to 1200 & 24.17 & 30 & 50 & 140 & 9 & 57 & 22 & 0 & 9 \\
Tegal & $<1000$ & 66.67 & 53.75 & 0 & 45 & 33 & 24 & 0 & 23.5 & 0 \\
\hline
\end{tabular}

Abbreviations: Ditylenchus sp. (Dit), Helicotylenchus sp.(Hel), Rotylenchulus sp. (Roty), Pratylenchus sp. (Praty), Hoplolaimus sp. (Hoplo).
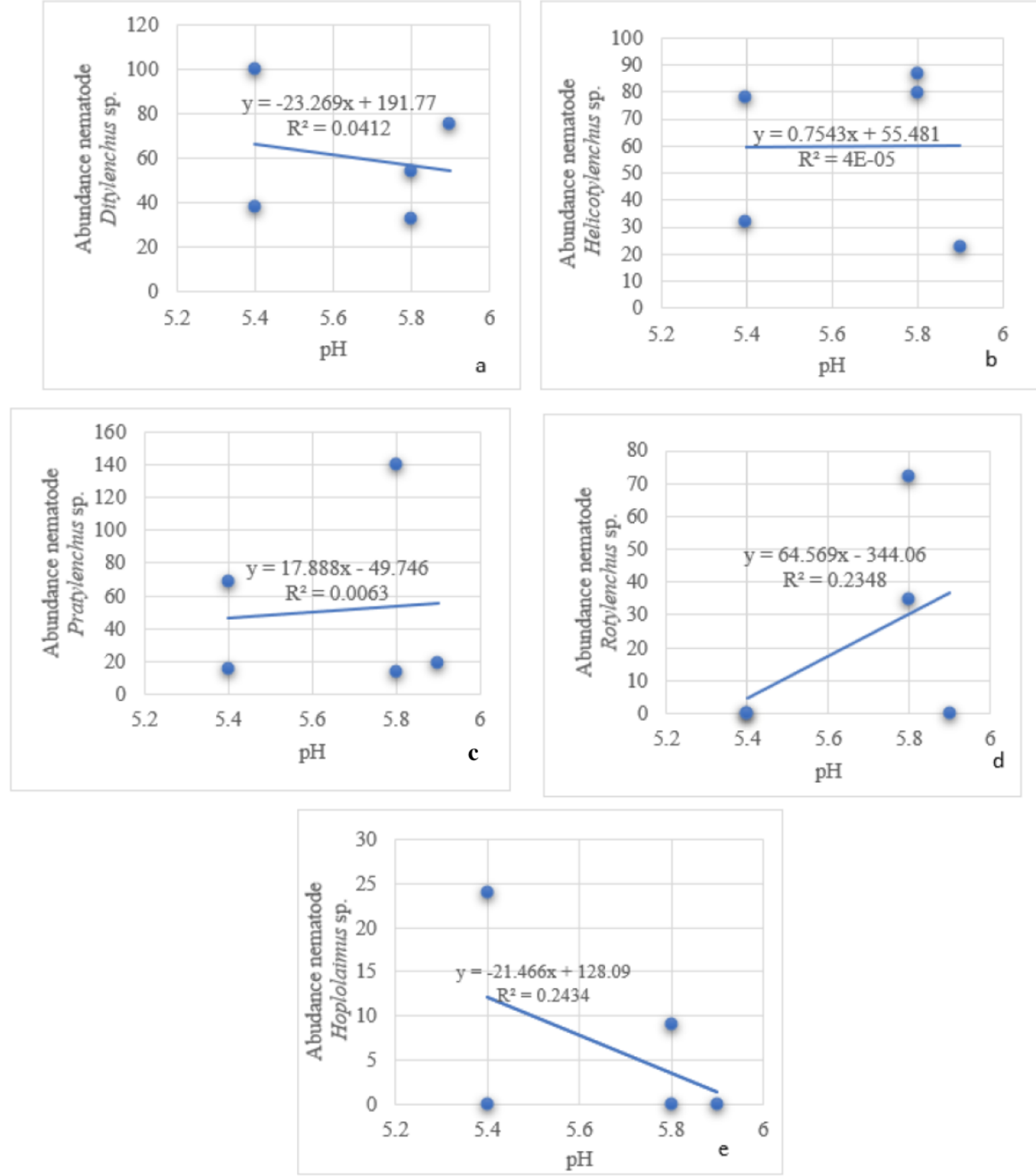

Figure 2: pH Influences on Parasitic Nematodes Abundance (a): Ditylenchus sp.; (b) Helicotylenchus sp.; (c) Rotylenchulus sp.; (d) Pratylenchus sp.; (e) Hoplolaimus sp. 
from the root with 53.75 individuals $5 \mathrm{~g}^{-1}$ tuber. As from soil, 57 individuals $100 \mathrm{~g}^{-1}$ soil were found at $1000 \mathrm{~m}$ to $1200 \mathrm{~m}$ a.s.1. Genus Rotylenchulus sp. was mostly found at $1000 \mathrm{~m}$ to $1200 \mathrm{~m}$ a.s.1 from soil and root with 50 individuals $5 \mathrm{~g}^{-1}$ tuber and 22 individuals $100 \mathrm{~g}^{-1}$ soil. Genus Pratylenchus sp. was mostly found at $1000 \mathrm{~m}$ to $1200 \mathrm{~m}$ a.s.1 from root with 140 individuals $5 \mathrm{~g}^{-1}$ tuber, as from soil, 23.5 individuals $100 \mathrm{~g}^{-1}$ soil were found at $<1000 \mathrm{~m}$ a.s.1. Genus Hoplolaimus sp. was mostly found at $1201 \mathrm{~m}$ to $1400 \mathrm{~m}$ a.s.l from soil with 24 individuals $100 \mathrm{~g}^{-1}$ of soil.

\section{Influence of soil abiotic factor on parasitic nematodes}

Temperature influences on parasitic nematodes abundance: Temperature is one of the soil factors that influences microbe's activities in the soil, not to mention the nematodes. The average temperature for nematodes' activity falls between $5{ }^{\circ} \mathrm{C}$ to $40{ }^{\circ} \mathrm{C}$. Nematodes activity will increase at $25{ }^{\circ} \mathrm{C}$ and decrease at $30{ }^{\circ} \mathrm{C}$. It will also inactivate at $40{ }^{\circ} \mathrm{C}$ (Mulyadi, 2009). Based on the research, temperature influenced the five found parasitic nematodes (Ditylenchus sp., Helicotylenchus sp., Pratylenchus sp., Hoplolaimus sp. and Rotylenchulus sp.) at different temperature. The average temperature in this research fell between $22.5^{\circ} \mathrm{C}$ to $25.5^{\circ} \mathrm{C}$. This corresponds Mulyadi's opinion (2009) stating that the optimal temperature for nematodes activities is between $15{ }^{\circ} \mathrm{C}$ to $30{ }^{\circ} \mathrm{C}$. Temperature influences Helicotylenchus sp. greatly by $30 \%$. According to the linear regression, the temperature positively influenced Helicotylenchus sp. abundance. This corresponds to a research by Pinochet and Cisneros (1986) stating that Helicotylenchus sp. population reaches the highest number in summer with 320 nematodes in $500 \mathrm{~cm}^{3}$ soil. As well as in linear regression of Pratylenchus sp. which is known to positively influence the abundance of Pratylenchus sp. nematode. This corresponds to Inomoto and Olivera's research (2008) showing positive influence of the temperature between $23.8^{\circ} \mathrm{C}$ to $26.7^{\circ} \mathrm{C}$ on Pratylenchus brachyuru development and reproduction.

\section{pH influences on parasitic nematodes abundance:} $\mathrm{pH}$ is one of the crucial factors in soil that influences its physical, chemical and biological characteristics and may affect plant growth and organism life in soil such as nematodes (Calanska et al., 2006). Soil pH left diverse influence on some nematodes genera. Every nematode genus possesses its optimal $\mathrm{pH}$ to grow. The result showed that $\mathrm{pH}$ influenced those five nematodes (Ditylenchus sp., Pratylenchus sp. Hoplolaimus sp. Rotylenchulus sp., and Helicotylenchus sp.) at various elevations. $\mathrm{pH}$ influenced Hoplolaimus sp. more greatly by $24 \%$ than other nematodes. Based on the linear regression above, $\mathrm{pH}$ directly influenced Hoplolaimus sp. abundance negatively. This conforms Matute (2013) showing that $\mathrm{pH}$ negatively influences several nematodes such as Hoplolaimus galeatus, and survived best at $\mathrm{pH}$ 6.0. $\mathrm{pH}$ influence on Helicotylenchus sp. abundance is known to be very weak which is only by $0.004 \%$. Simon et al. (2018) state in their research that Helicotylenchus sp. is never found in soil $\mathrm{pH}$ under 4.3, neither in organic or mineral soil. It is mostly found in soil with $\mathrm{pH}$ above 6.0. This proves that Helicotylenchus sp. is mostly found in $\mathrm{pH}$ higher than 6 , while the average $\mathrm{pH}$ in this research was only 5.6. This caused low encounter of Helicotylenchus sp. If the environmental condition such as $\mathrm{pH}$ is not in its optimal condition for nematodes to reproduce, many nematodes may fail to reproduce and reach their adult phase and the plant-parasitic nematodes population may as well decrease (Northon, 1989).

\section{Organic matter influence on parasitic nematodes} abundance: Organic matter directly gives negative influence on plant-parasitic nematodes growth and development. Organic matter decomposition results as a toxic chemical compound to some genera of parasitic nematodes (Mulyadi, 2009). Based on the result of the research, organic matter influenced those five parasitic nematodes (Ditylenchus sp., Helicotylenchus sp., Pratylenchus sp., Hoplolaimus sp., and Rotylenchulus sp.). It left diverse influence on each parasitic nematode. In this research, organic matter influenced Pratylenchus sp. greatly by $72 \%$. Based on the above linear regression, organic matter is known to directly and positively influence Pratylenchus sp. nematode abundance. This conforms Mutala'liah et al. (2017) saying that organic matter positively correlates with Pratylenchus sp. nematode population. Cadet and Thioulouse (1998) state in their research that Pratylenchus coffeae prefers all types of soil with high organic matter content. When the organic matter is high, Pratylenchus sp. nematode abundance will also be high. As in potato plants, there is no real difference between giving organic matter and not giving organic matter on P. penetrans and $M$. hapla population as it does not decrease their population (Kimpinski et al., 2003). In bean plants, however, additional organic matter may decrease $M$. incoginita population by $90 \%$ (Akhtar, 2000). 

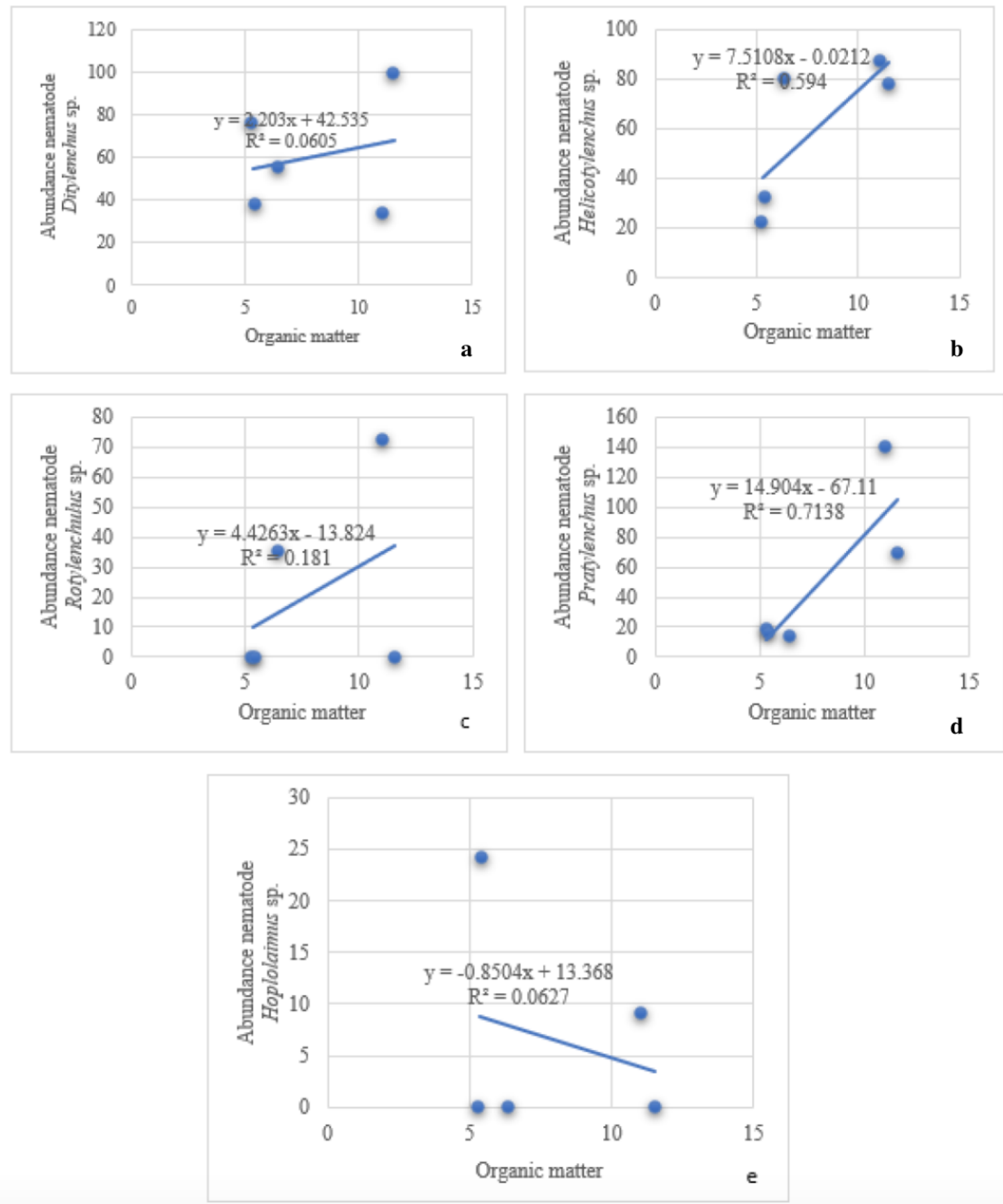

Figure 3: Organic matter influence on parasitic Nematodes abundance: (a). Pratylenchus sp.; (b) Rotylenchulus sp.; (c) Ditylenchus sp.; (d) Helicotylenchus sp.; (e) Hoplolaimus sp.

Parasitic nematodes diversity index on garlic at various elevations

Diversity index is information that can determine the relationship between the sample area and the number of nematodes was encountered. Parasitic nematodes diversity index at various elevations was considered low, approximately between 0.90 to 1.36 (Table 3). According to Hariyadi et al. (2019), value of the diversity index is between 0 to 7 with criteria: 0 to 2 (low), 2 to 3 (medium), and $>3$ (high). Stable, 
widespread and homogene community possesses lower diversity index than mosaic forest ecosystem or region with periodically occurred disasters.

Table 3: Parasitic nematodes Diversity Index on garlic at various elevations.

$\begin{array}{ll}\text { Elevation (m a.s.l) } & \text { Parasitic nematodes diversity index } \\ >1600 & 0.90 \\ 1401 \text { to } 1600 & 1.29 \\ 1201 \text { to } 1400 & 1.34 \\ 1000 \text { to } 1200 & 1.36 \\ <1000 & 0.97\end{array}$

The data in Table 3 showed that at various elevations, relatively similar diversity index is found. This shows that habitat condition of garlic cropping land in survey is relatively homogene. Minor range of elevation may contribute to similar number of living parasitic nematodes found in all elevations based on the total genus of parasitic nematodes found.

\section{Parasitic nematodes dominance on garlic plants at vari- ous elevation}

This research showed that at $>1600 \mathrm{~m}$ a.s.l elevation, the dominant parasitic nematode was Ditylenchus sp. with $41.55 \%$ (Figure 4). Ditylenchus sp. was also dominant at $1201 \mathrm{~m}$ to $1400 \mathrm{~m}$ a.s.1 with $11.83 \%$ appearance and at $<1000 \mathrm{~m}$ a.s.1 with $24.61 \%$ appearance. Yavuzaslanoglu et al. (2015) finds that Ditylenchus sp., activity depends on soil texture and $\mathrm{pH}$. Nematodes activity is found to be higher in sandy soil with $\mathrm{pH} 7$ than in clay soil with $\mathrm{pH}$ 5. Beside, $D$. dipsaci is mostly found at $22{ }^{\circ} \mathrm{C}$ than at other temperatures $\left(17^{\circ} \mathrm{C}\right.$ and $\left.27^{\circ} \mathrm{C}\right)$. This research found that clay loam texture with $\mathrm{pH} 5.9$ and at $22.5{ }^{\circ} \mathrm{C}$ was dominant at $>1600 \mathrm{~m}$ a.s.l elevation while at $<1000 \mathrm{~m}$ a.s.l, sandy loam texture with $\mathrm{pH} 5.4$ and at $25.5^{\circ} \mathrm{C}$ temperature was dominant. Nematodes are commonly found in soil with sandy texture. However, it is possible for the nematodes to be found in other type of soils. The condition is affected by nematodes migration ability through soil particles. At 1401 to $1600 \mathrm{~m}$ a.s.1, the dominant parasitic nematode was Helicotylenchus sp. with $16.97 \%$ (Figure 4). $H$. multicinctus was found in banana plants at all elevations, especially, higher elevations $(<1600 \mathrm{~m}$ a.s.1). It was found with quite low dominance at lower elevations (< $646 \mathrm{~m}$ a.s.1). Helicotylenchus dibystera which was dominant at higher elevations (Kamira et al., 2013). This nematodes distribution is strongly influenced by elevation and temperature. According to Pinochet and Cisneros (1986), Helicotylenchus dibystera population reaches its highest population in summer months with high temperature and population abundance reaching < 320 individuals in $500 \mathrm{~cm}^{3}$ soil. The dominant parasitic nematode at $1000 \mathrm{~m}$ to $1200 \mathrm{~m}$ a.s.1 was Pratylenchus sp. with 16.83 \%. Kamira et al. (2013) finds that Pratylenchus goodeyi is a dominant species at higher elevations (>1200 m a.s.l) yet Pratylenchus spp. distribution becomes uncertain at lower elevations (9 to 646) $\mathrm{m}$ a.s.1.

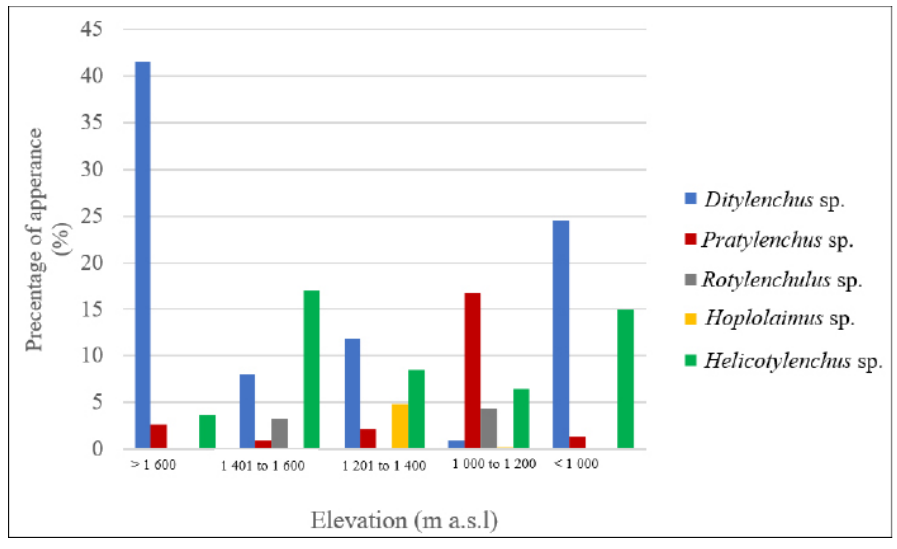

Figure 4: Parasitic nematodes dominance on garlic plants at various elevation.

\section{Conclusions and Recommendations}

In conclusion, the parasitic nematodes found were Ditylenchus sp., Rotylenchulus sp., Hoplolaimus sp., Helicotylenchus sp., and Pratylenchus sp. Abiotic factors such as temperature has positive influence to Helicotylenchus sp abundance. Hoewever $\mathrm{pH}$ has negative the significant effect to Hoplolaimus sp. nematodes abundance. Organic matter has positive influence to Pratylenchus sp. nematodes in garlic. Diversity index of parasitic nematodes in garlic at various elevation was considered low, ranging between 0.90 to 1.36 . Based on $>1600 \mathrm{~m}$ a.s.1, $1201 \mathrm{~m}$ to 1400 $\mathrm{m}$ a.s.1 and $<1000 \mathrm{~m}$ a.s.1 elevations, the dominant parasitic nematode in garlic was Ditylenchus sp., while at $1401 \mathrm{~m}$ to $1600 \mathrm{~m}$ a.s.l, the dominant parasitic nematode was Helicotylenchus sp., and at $1000 \mathrm{~m}$ to $1200 \mathrm{~m}$ a.s.l elevation, the dominant parasitic nematode was Pratylenchus sp.

\section{Acknowledgments}

The authors would like to thank Universitas Gadjah Mada for the research funded with scheme by RTA 
(Rekognisi Tugas Akbir - Student Final Project Recoqnition) with Contract No. 2129/UN1/DITLIT/ DIT-LIT/LT/2019.

\section{Novelty Statement}

Plant-parasitic nematodes identification in garlic is extremely necessary since there is very little information about plant-parasitic nematodes of garlic in Indonesia. Based on analysis process, the authors found five parasitic nematodes genera in garlic, such as $D i-$ tylenchus sp., Helicotylenchus sp., Hoplolaimus sp., Rotylenchulus sp., and Pratylenchus sp.

\section{Author's Contribution}

ASW conceptualized and designed the study, elaborated the intellectual content, performed literature search, carried out experimental studies, data acquisition, data analysis, statistical analysis, manuscript preparation. SI defined the intellectual content, carried out literature search, manuscript review/revision, and guarantor. MIM and NVM elaborated the intellectual content, performed literature search, performed manuscript review/ revision, and guarantor.

\section{Conflict of interest}

The authors declares that there is no conflict of interests regarding the publication of this article.

\section{References}

Akhtar, M. 2000. Effect of organic and urea amendments in soil on nematode communities and plant growth. Soil Biol. Biochem., 32(4): 573-575. https://doi.org/10.1016/S00380717(98)00147-3

Bezooijen, J. 2006. Methods and techniques for nematology. Wageningen. Netherland.

Cadet, P. and J. Thioulouse. 1998. Identification of soil factors that relate to plant parasitic nematode communities on tomato and yam in the French West Indies. Appl. Soil Ecol. , 8(1-3): 35-49. https://doi.org/10.1016/S09291393(97)00068-1

Calanska, A., G. Labanowski and D. Sas. 2016. Root lesio nematodes (Pratylenchus spp.) in ornamental plant nurseries-influenceof soil texture, acidity, salinity, and organic matter content. Commun. Biometry Crop. Sci., 11(2):98-104.
Eviati and Sulaeman. 2009. Technical instructions: Chemical analysis of soil, plants, water, and fertilizers ( $\left.2^{\text {nd }} e d.\right)$. Institut Pertanian Bogor, Bogor, Indonesia.

George, S.A. and K. Moktan. 2010. Bloat nematode problem on garlic: Symptoms, distribution, and management guidelines. Cornell University, New York, USA.

Hariyadi, R. Machrizal, R.H. Dimenta, K. Khairul, R. Hasibuan and H.S.B. Gultom. 2019. Fish biodiversity in false gharial habitat (Tomistoma schlegelii Müller, 1838) in Labuhan Batu district. IOP Conf Ser Earth Environ. Sci., 348(012027):1- 6. https://doi. org/10.1088/1755-1315/348/1/012027

Ifo S.A., J.M. Moutsambote, F. Koubouana, J. Yoka, S.F. Ndzai, L.N.O.B. Kadilamio, H. Mampouya, C. Jourdain, Y. Bocko, A.B. Mantota, M. Mbemba, D.M. Sokath, R. Odende, L.R. Mondzali, Y.E.M. Wenina, B.C. Ouissika and L.J. Joel. 2016. Tree species diversity, richness, and similarity in intact and degraded forest in the tropical rainforest of the Congo basin: case of the forest of Likouala in the Republic of Congo. Int. J. For. Res., 2:1-12. https://doi. org/10.1155/2016/7593681

Inomoto, M.M and C.M.G. Oliveira. 2008. Coffee- associated Pratylenchus spp., ecology and interactions with plants. p. 51-64. In: Souza R.M. (eds.), Plant-parasitic nematodes of coffee. Springer. Dordrecht. https://doi. org/10.1007/978-1-4020-8720-2_4

Kamira M., S. Hauser, P. Van Asten, D. Coyne and H.L. Talwana. 2013. Plant parasitic nematodes associated with banana and plantain in eastern and western democratic Republic of Congo. Nematropica, 43(2):216-225.

Kimpinski,J., C.E. Galiant, R.Henry,J.A.Macleod, J.B. Sanderson and A.V. Sturz. 2003. Effect of compost and manure soil amandements on nematodes and on yields of potato and barley: a 7-year study. J. Nematol., 35(3):289-293.

Mahmoud, M.A.Y. and E.M.A. Wafaa. 2021. New approach for biocontrolling root-knot nematode, Meloidogyne incognita on Cowpea by commercial fresh oyster mushroom (Pleurotus ostreatus). Jordan J. Biol. Sci., 14 (1): 173-177.

Mai, W.F. and M.G. Peter. 1996. Plant-parasitic nematodes: A pictorial key to genera 5 ed. Comstock Pub. Associates, Cornell University Press, Ithaca, New York, USA. https://doi. 
org/10.7591/9781501728419

Matute M. 2013. Soil nematodes of Brassica rapa: influence of temperature and $\mathrm{pH}$. Adv. Nat. Sci. 6(4):20-26.

Mulyadi.2009. Nematologi pertanian [Agricultural nematology]. Gadjah Mada Press. ogyakarta, Indonesia

Mutala'liah, I. Siwi and S.P. Nugroho. 2017. Relationship of soil abiotic factors with population abundance and vertical distribution of root lesion nematode in robusta coffee plantation. Pak. J. Nematol., 35(2):183-196. https://doi. org/10.18681/pjn.v35.i02.p183-196

Nicol, J.M., S.J. Turner, D.L. Coyne, L. Nijs, S. den Hockland and Z.T. Maafi. 2011. Current nematode threats to world agriculture. p. 21-43. In: Jones, J., G. Gheysen and C. Fenoll (eds), Genomics and molecular genetics of plantnematode interactions. Springer. Dordrecht. https://doi.org/10.1007/978-94-007-04343_2

Northon, D.C. 1989. Abiotic soil factors and plantparasitic nematode communities. J. Nematol., 21(3):299-307.
Pinochet V.J and C. Tomas. 1986. Seasonal fluctuations of nematode populations in three Spanish vineyard. Revue Nématol., 9(4):391-398.

Rahman, S.A., S.N.M. Zain, M.Z.B. Mat, A.K. Sidam, R.Y. Othman and Z. Mohamed. 2014. Population distribution of plant parasitic nematodes of banana in Peninsular Malaysia. Sains Malaysiana, 43(2):175-183.

Simon A.C.M., D.H.D.L. Nicora, T.L. Niblack, E.A. Dayton, D. Tomashefski and P.A. Paul. 2018. Cropping practices and soil properties associated with plant-parasitic nematodes in corn fields in Ohio. Plant Dis., 102(12):25192530. https://doi.org/10.1094/PDIS-03-180471-RE

Yavuzaslanoglu E., A. Dikici, H. Elekcioglu and M. Aydogdu. 2015. Distribution of nematodes on onion and their relationship with soil physicochemical characteristics in Karaman province, Turkey. Türk. Entomol. Derg., 39(3):251-259. https://doi.org/10.16970/ ted. 48085 